\title{
Snails promote methane release from a freshwater lake ecosystem
}

\author{
Xiao Xu' ${ }^{1}$, Wei Zhao ${ }^{1}$, Ming Xiao ${ }^{1 *}$, Jingxin Huang ${ }^{2}$, Changming Fang ${ }^{2}$, Bo Li ${ }^{2}$ and Ming $\mathrm{Nie}^{1,2,3 *}$ \\ ${ }^{1}$ College of Life and Environment Science, Shanghai Normal University, Shanghai, China \\ ${ }^{2}$ Coastal Ecosystems Research Station of Yangtze River Estuary, Ministry of Education Key Laboratory for Biodiversity Science and Ecological Engineering, \\ Institute of Biodiversity Science, Fudan University, Shanghai, China \\ ${ }^{3}$ Centre for Watershed Ecology, Institute of Life Science, Nanchang University, Nanchang, China
}

\author{
Edited by: \\ Pete Falloon, Met Office, UK \\ Reviewed by: \\ Nathaniel Kenneth Newlands, \\ Federal Government of Canada, \\ Canada \\ Busineni Devasena, Sri \\ Venkateswara Veterinary University, \\ India \\ ${ }^{*}$ Correspondence: \\ Ming Xiao, College of Life and \\ Environment Science, Shanghai \\ Normal University, Guilin Road, \\ No.100, Xuhui District, Shanghai \\ 200234, China \\ e-mail:xiaom88@shnu.edu.cn; \\ Ming Nie, Centre for Watershed \\ Ecology, Institute of Life Science, \\ Nanchang University, Xuefu Road, \\ No.999, Honggutan New District, \\ Nanchang 330031, China \\ e-mail:mnie0928@gmail.com
}

Benthic fauna, as ecosystem engineers, can strongly affect microbial-driven ecosystem biogeochemical cycling. However, the effects of benthic fauna, especially epifauna, on $\mathrm{CH}_{4}$ cycling remain still elusive. In this study, $\mathrm{CH}_{4}$ effluxes were both measured along a gradient of snail density in a freshwater lake ecosystem in China, and monitored in manipulated laboratory microcosms with and without snails. Field $\mathrm{CH}_{4}$ efflux was significantly increased with snail density. Likewise, the stimulating effects of freshwater snails on $\mathrm{CH}_{4}$ effluxes were evident in the homogenized indoor microcosms. These results show that snails can stimulate $\mathrm{CH}_{4}$ efflux in the freshwater lake ecosystem. Moreover, the average efflux of $\mathrm{CH}_{4}$ emitted from snails' habitats has reached $15.33 \mathrm{mg} \mathrm{CH}_{4}-\mathrm{C}$ $\mathrm{m}^{-2} \mathrm{~d}^{-1}$. By comparing with those emitted from vegetated coastal marsh and alpine wetland, this data indicates that snails' habitats are strong sources of $\mathrm{CH}_{4}$ in a freshwater ecosystem. This study suggests identifying and modeling epifauna activity as a function of $\mathrm{CH}_{4}$ cycling could improve the mechanistic understanding of wetland biogeochemical cycling responses to climate change.

Keywords: aquatic fauna, invertebrate-microorganism interaction, methanogens, $\mathrm{CH}_{4}$ oxidizing bacteria, $\mathrm{CH}_{4}$ cycling, freshwater ecosystem

\section{INTRODUCTION}

Benthic fauna are known as ecosystem engineers, whose activities can create unique microniches for microorganisms to inhabit (Laverock et al., 2011), and increase resource availabilities for microbial metabolism (Mermillod-Blondin and Rosenberg, 2006). Consequently, altered microbial community structure and composition due to fauna activities could largely influence microbial-driven ecosystem biogeochemical cycling (MermillodBlondin and Rosenberg, 2006; Laverock et al., 2011).

Wetlands are the largest natural source of $\mathrm{CH}_{4}$ to the atmosphere, contributing $217 \mathrm{Tg}$ annually (IPCC, 2013). Wetland $\mathrm{CH}_{4}$ effluxes are primarily driven by net effects of two microbial processes, the $\mathrm{CH}_{4}$ production and oxidation (Whalen, 2005). However, the effects of benthic fauna, especially epifauna, on $\mathrm{CH}_{4}$ cycling are very limited (Weyhenmeyer et al., 2009). Hence, present study was planned to establish the effects of epifauna on $\mathrm{CH}_{4}$ cycling in freshwater ecosystems. Understanding the potential roles of epifauna in regulating $\mathrm{CH}_{4}$ cycling can not only fully reveal the dynamic processes of $\mathrm{CH}_{4}$-cycling in freshwater ecosystems, but also throw a new light on their ecosystem processes in the process-based $\mathrm{CH}_{4}$ models (Cao et al., 1996).

Snails are known as a common epifauna that live on the surface sediment in aquatic ecosystems, including lakes and ponds. They can forage on attached microorganisms such as algae, and sediment organic carbon within the upper few millimeters of the sediment (Zheng et al., 2011). They were also found to enhance
Oxygen $\left(\mathrm{O}_{2}\right)$ consumption (Zheng et al., 2011). Therefore, snails have potentially profound effects on microbial activities, thus may affect $\mathrm{CH}_{4}$ efflux. In this study, both field and microcosm experiments were performed to elucidate the potential roles of snails in $\mathrm{CH}_{4}$ cycling. $\mathrm{CH}_{4}$ effluxes were measured along a gradient of snail density in the largest freshwater lake in China. Sediment properties and two microbial-mediated $\mathrm{CH}_{4}$ processes $\left(\mathrm{CH}_{4}\right.$ oxidation and production potential rates) of the top layer of sediments were characterized. Furthermore, sediment sample as a common growth substrate was incubated with and without snail addition at the constant conditions to determine microbial capacity to produce and oxidize $\mathrm{CH}_{4}$.

\section{MATERIALS AND METHODS STUDY SITE AND FIELD EXPERIMENTAL DESIGN}

Poyang Lake $\left(28^{\circ} 24^{\prime}-29^{\circ} 46^{\prime} \mathrm{N}, 115^{\circ} 49^{\prime}-116^{\circ} 46^{\prime} \mathrm{E}\right)$, the largest freshwater lake in China, is located in the northern part of Jiangxi Province along the southern bank of the middle reaches of the Yangtze River. Poyang Lake exhibits a large seasonal water level fluctuation, with a maximum and water depth of $17.6 \mathrm{~m}$ in July and a minimum water depth of $10.5 \mathrm{~m}$ in January on average (Wang et al., 2007). In winter, more than $90 \%$ of its water can be lost (Wang et al., 2007). As the water level declined, the large inland sea could be divided into numerous sub-lakes, and vast areas of flat grass-covered marshlands become exposed. This lake has a monsoon climate of subtropical zone. The mean 
annual temperature is $17.2^{\circ} \mathrm{C}$. The mean annual precipitation is $1482.3 \mathrm{~mm}$ (46\% falls in April-June), and the mean annual evaporation is $1184 \mathrm{~mm}$ (Wang et al., 2007). The sediment texture is mainly hard clay and fine sand (Wang et al., 2007).

Freshwater snails are dominant epifauna in Poyang Lake, account for $24.7 \%$ and $29.2 \%$ in total density $\left(659\right.$ ind $\mathrm{m}^{-2}$ ) and biomass (187.3 $\mathrm{g} \mathrm{m}^{-2}$ ) of benthic fauna (Wang et al., 2007). According to the hydrologic/weather conditions and snail growth, field sampling was only conducted in autumn. Due to habitats covering by water, few snails can be found during flooded seasons (from April to July). Freshwater snails generally start to reproduce in late summer and reach maximum values of density and biomass in autumn because of accommodative growth temperature.

To avoid disturbances from agricultural and grazing activities, the in situ experiment was conducted in Banghu Lake, the isolated sub-lake located in the core area of Poyang Lake, in September, 2011. Eight sampling sites were carefully selected along the lakeshore within $1 \mathrm{~km}$ based on the gradient of epifaunal density. None of infauna was found in the upper $5 \mathrm{~cm}$ sediment of these sampling sites. The mean distance between each two sampling sites is about $18 \mathrm{~m}$. All these sites have similar sediment textures (hard clay) and hydrologic regime (a water depth of $3-5 \mathrm{~cm}$ and similar water flow velocity). The only epifauna observed at these sites were freshwater snails. Over $80 \%$ of the total freshwater snails belonged to Viviparidae and Melaniidae. All snails had similar size (length $\sim 12 \mathrm{~mm}$ ) across study sites. To ensure that the samples were representative of study sites, each site ( $1 \mathrm{~m}$ wide $\times 5 \mathrm{~m}$ long) was evenly divided into three sub-sites for sampling. Vegetation zones with the mean straight-line distance of $3 \mathrm{~m}$ from snail habitats were dominated by a $\mathrm{C}_{3}$ grass Carex lasiocarpa. No visible litter fall occurred at any of the sites during sampling.

\section{$\mathrm{CH}_{4}$ EFFLUX}

$\mathrm{CH}_{4}$ efflux measurements from each sub-site were made using a static chamber technique. The Plexiglas chamber consisted of two compartments. The top compartment $(40 \times 40 \mathrm{~cm}$ wide and $50 \mathrm{~cm}$ high) was equipped with a sampling port and a $12 \mathrm{~V}$ fan was located on the top panel inside the chamber for mixing air. The bottom compartment $(40 \times 40 \mathrm{~cm}$ wide and $20 \mathrm{~cm}$ high) was inserted carefully into the sediment to a depth of about $10 \mathrm{~cm}$ with as little disturbance as possible before sampling, and then mounted the top compartment and sealed gastight. Headspace gas samples $(50 \mathrm{ml})$ were taken at time zero and after periods of $20 \mathrm{~min}$ in polypropylene syringe equipped with three-way stopcocks. Gas samples were then injected into $100-\mathrm{mL}$-evacuated gas bags (Delin Inc, Dalian, China).

$\mathrm{CH}_{4}$ concentrations were determined with a gas chromatography (Agilent HP5340 equipped with FID and a 2-m Porapak Q (60/80 mesh) column, Agilent Technologies Inc., Santa Clara, CA, USA). The oven, injector, and detector temperatures were set at 80,200 , and $330^{\circ} \mathrm{C}$, respectively. The carrier gas $\left(\mathrm{N}_{2}\right)$ flow rate was $30 \mathrm{~mL} \mathrm{~min}^{-1}$, and the flow rates of flaming gases $\left(\mathrm{H}_{2}\right.$ and synthetic air) were set at 40 and $400 \mathrm{~mL} \mathrm{~min}^{-1}$, respectively. Calibration was performed with a standard $\mathrm{CH}_{4}$ gas of 9.9 ppm.

\section{SEDIMENT SAMPLING}

After measuring $\mathrm{CH}_{4}$ efflux, three cores in each sub-site were randomly taken from the top $5 \mathrm{~cm}$ sediment using a $2.5-\mathrm{cm}$ diameter auger, and then thoroughly mixed. The mixed samples were handpicked to remove stones and snail shells. Samples were stored at $4^{\circ} \mathrm{C}$ for determining potential rates of $\mathrm{CH}_{4}$ oxidation (PMO) and production (PMP), and chemical properties.

\section{$\mathrm{CH}_{\mathbf{4}}$ OXIDATION AND PRODUCTION POTENTIALS}

To determine the PMO and PMP rate, sediment-water slurries were prepared using $30 \mathrm{~g}$ fresh sediment and $30 \mathrm{~mL}$ sterile deionized water, and then shook $(150 \mathrm{rpm})$ for $30 \mathrm{~min}$ at room temperature. PMO was determined with a method modified from Bodelier and Frenzel (1999). Four Labco exetainers (12 mL, Labco Limited, Buckinghamshire, UK) were added with $5 \mathrm{~mL}$ of the slurry samples, and were purged with $\mathrm{CH}_{4}$-free gas $\left(20 \% \mathrm{O}_{2}, 80 \% \mathrm{~N}_{2}\right)$ for $10 \mathrm{~min}$. To activate the $\mathrm{CH}_{4}$-oxidizing bacteria, $0.3 \mathrm{~mL}$ of pure $\mathrm{CH}_{4}$ gas $(99.9 \%)$ was injected into each exetainer through a rubber septum and the exetainers were pre-incubated in dark at $30^{\circ} \mathrm{C}$ for 2 days. All exetainers were then purged again with $\mathrm{CH}_{4}$-free gas, and injected $0.3 \mathrm{~mL}$ of pure $\mathrm{CH}_{4}$ gas, and incubated for 24, 48, 72, and $96 \mathrm{~h}$, respectively. At the end of incubation $0.1 \mathrm{~mL}$ of $\mathrm{ZnCl}_{2}$ solution $(50 \%$, $\mathrm{w} / \mathrm{v}$ ) was injected into each exetainer, which was shaken to stop $\mathrm{CH}_{4}$ oxidation. The decrease in $\mathrm{CH}_{4}$ concentration in the headspace was monitored with the gas chromatograph (GC) at 24-h intervals. The PMO rate was calculated from the slope of linear regression of $\mathrm{CH}_{4}$ concentration against incubation time $\left(R^{2}>0.85\right)$.

PMP was determined with a method modified from Bodelier et al. (2006). Five $\mathrm{mL}$ of the slurry was also transferred to four Labco exetainers. The exetainers were flushed with pure $\mathrm{N}_{2}$ (99.999\%) for $10 \mathrm{~min}$. To activate methanogens, the slurry was pre-incubated in dark at $30^{\circ} \mathrm{C}$ for 2 days. All exetainers were flushed again with pure $\mathrm{N}_{2}$, and the slurry sample in each exetainer was incubated for 24, 48, 72, and $96 \mathrm{~h}$, respectively. At the end of incubation $0.1 \mathrm{~mL}$ of $\mathrm{ZnCl}_{2}$ solution $(50 \%$, w/v) was injected into each exetainer, which was shaken to stop methanogenesis. Accumulation of $\mathrm{CH}_{4}$ in the headspace was monitored with the GC at 24-h intervals. The PMP rate was calculated from the slope of linear regression of $\mathrm{CH}_{4}$ concentration against incubation time $\left(R^{2}>0.85\right)$.

\section{CHEMICAL ANALYSIS}

Sediment samples were oven-dried at $50^{\circ} \mathrm{C}$ to constant weight and then ground and passed through 100-micron meshes. Sediment $\mathrm{pH}$ was measured with a glass electrode in the sediment supernatant $(1: 5, \mathrm{w} / \mathrm{v}) . \mathrm{NH}_{4}^{+}$and $\mathrm{NO}_{3}^{-}\left(\mathrm{NO}_{3}^{-}+\mathrm{NO}_{2}^{-}\right)$ were extracted with $2 \mathrm{M} \mathrm{KCl}(1: 4, \mathrm{w} / \mathrm{v})$ and determined colorimetrically with discrete auto analyzer (SmartChem200, WestCo, America). Dissolved total nitrogen (DTN) and organic carbon (DOC) were extracted from sediment samples using $0.5 \mathrm{M}$ $\mathrm{K}_{2} \mathrm{SO}_{4}(1: 4, \mathrm{w} / \mathrm{v})$ and analyzed with a TOC analyzer (vario TOC cube, Elementar, Germany). DON was calculated as DTN $\left(\mathrm{NH}_{4}^{+}+\mathrm{NO}_{3}^{-}\right)$. Total carbon (TC) and nitrogen (TN) were determined with an N/C analyzer (Flash EA 1112Series, Thermo, Italy). 


\section{MICROCOSM INCUBATION EXPERIMENT}

Individual snails as well as sediments were also collected from the sampling sites with highest snail density for indoor incubation. Sediments were air-dried, ground, gently sieved through a $2 \mathrm{~mm}$ mesh, and thoroughly homogenized. $3.2 \mathrm{~kg}$ of the defaunated sediment and $1.6 \mathrm{~L}$ sterile deionized water were transferred into each of eight microcosms $(25 \times 16 \mathrm{~cm}$ inner diameter (i.d.) PVC cylinders) to a depth of about $15 \mathrm{~cm}$. Microcosms were stabilized at room temperature $\left(22 \pm 2^{\circ} \mathrm{C}\right)$ for 7 days and the overlying water was maintained at a depth of $3-5 \mathrm{~cm}$. Snails had been washed and acclimatized in a larger container with the same experimental conditions for 1 week before being introduced to these microcosms. After the stabilization period, 10 snails were added to each of 4 microcosms, equivalent to a density of 500 ind $\mathrm{m}^{-2}$, while 4 microcosms were kept as defaunated controls. $\mathrm{CH}_{4}$ effluxes were measured every 7 days during a 49-day incubation. During $\mathrm{CH}_{4}$ efflux measurements, the microcosms were sealed with $15 \times 16 \mathrm{~cm}$ i.d. PVC lids. The center of the top lid was equipped a $4 \mathrm{~mm}$ i.d. sampling port for sampling gas from the headspace. Efflux rates of $\mathrm{CH}_{4}$ were calculated as the difference in headspace concentrations between initial and final samples during a $20 \mathrm{~min}$ incubation period. At the end of incubation, snails in the microcosms were re-collected for calculating survival rate. $\mathrm{CH}_{4}$ concentrations were determined with the same method described above.

\section{STATISTICAL ANALYSES}

Polynomial regression analyses were used to determine the effects of snail density on $\mathrm{CH}_{4}$ efflux and microbial processes. One-way ANOVA was performed to determine the effects of freshwater snail on $\mathrm{CH}_{4}$ efflux in the indoor incubation. Pearson correlation analyses were performed to evaluate relationships between snail density, $\mathrm{CH}_{4}$ efflux, microbial activities, and sediment properties. Regression analyses and Pearson correlation analyses were performed with the software of Sigmaplot 12.3 (Systat Software, San Jose, CA, USA). One-Way ANOVA was performed using SPSS 17.0 (SPSS Inc., Chicago, IL, USA). Effects with $P<0.05$ were considered statistically significant.

\section{RESULTS}

\section{$\mathrm{CH}_{4}$ EFFLUX AND MICROBIAL ACTIVITIES}

Field $\mathrm{CH}_{4}$ efflux significantly increased with snail density (Figure 1). In support of data on $\mathrm{CH}_{4}$ effluxes, snail density was positively correlated with PMP rate (Figure 2A), and negatively correlated with $\mathrm{PMO}$ rate (Figure 2B). Likewise, snails $\left[F_{(1,4)}=6.919, P<0.05\right.$, Figure 3$]$ significantly promoted $\mathrm{CH}_{4}$ efflux compared to defaunated control during the 49-day incubation. At the end of indoor microcosm incubation, the survival rates of snails reached $>90 \%$.

\section{SEDIMENT PROPERTIES}

Sediment properties were listed in Table S1 (please see supplementary material in Data sheet 1 ). Sediment $\mathrm{pH}$ was positively correlated with snail density (Table 1). The concentrations of $\mathrm{NH}_{4}^{+}$and DON were significantly increased and decreased with

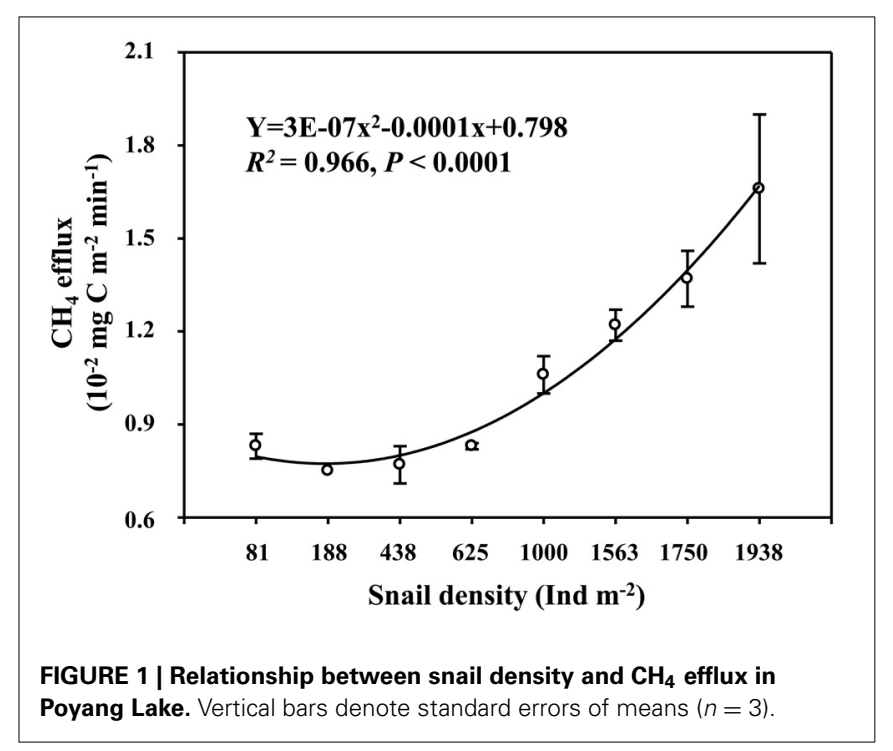

snail density, respectively (Table 1 ). Snail density had no significant Pearson relationships with $\mathrm{DOC}, \mathrm{NO}_{3}^{-}, \mathrm{TC}$, and $\mathrm{TN}$, respectively (Table $\mathbf{1}$ ).

\section{RELATIONSHIPS BETWEEN FIELD $\mathrm{CH}_{4}$ EFFLUX, MICROBIAL ACTIVITIES, AND SEDIMENT PROPERTIES}

$\mathrm{CH}_{4}$ efflux was positively correlated with $\mathrm{NH}_{4}^{+}$concentration (Table 1). $\mathrm{NH}_{4}^{+}$concentration was positively correlated with PMP rate and negatively correlated PMO rate (Table 1). Furthermore, sediment $\mathrm{pH}$ and DON was negatively and positively correlated with PMO rate (Table $\mathbf{1}$ ), respectively.

\section{DISCUSSION}

A higher $\mathrm{CH}_{4}$ efflux in the habitat with a greater snail density suggests that snail could stimulate $\mathrm{CH}_{4}$ efflux in the largest freshwater lake in China (Figure 1). Promoted potential of $\mathrm{CH}_{4}$ production and suppressed potential of $\mathrm{CH}_{4}$ oxidation across the gradient of snail density (Figure 2) suggest that snail-induced changes in microbial functioning relative to $\mathrm{CH}_{4}$ cycling are expected to result in more greenhouse gas effects, thus potentially contributing to a positive climate feedback.

These results are similar with previous study which found infauna could increase $\mathrm{CH}_{4}$ efflux in laboratory experiment (Weyhenmeyer et al., 2009). Furthermore, the effects of benthic fauna on $\mathrm{CH}_{4}$ efflux were extended from laboratory incubation to an open freshwater lake ecosystem. Field $\mathrm{CH}_{4}$ efflux is mediated by multiple biotic and abiotic factors (Dingemans et al., 2011). Influences of infauna (the benthic fauna have a habitat different from epifauna which live within the sediments rather than on the surface sediments) on $\mathrm{CH}_{4}$ efflux could not be completely excluded in field sampling because infauna usually inhabit in their tubes deeper than $5 \mathrm{~cm}$. Moreover, although no visible litter fall was found in these sampling sites, plant roots are known to stimulate $\mathrm{CH}_{4}$ efflux by secreting organic substrates for methanogens in rhizosphere zone (Laanbroek, 2010). By using a common soil, microcosm incubations were conducted at constant conditions to homogenize influences from other biotic and abiotic factors, 

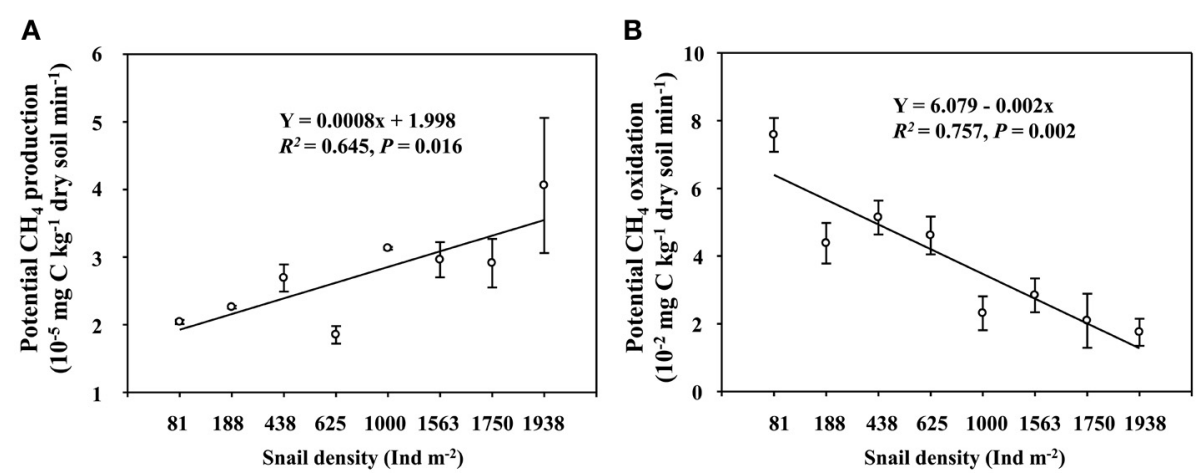

FIGURE 2 | The relationships of snail density with potential $\mathrm{CH}_{4}$ production (A), and potential $\mathrm{CH}_{4}$ oxidation (B) rates in the upper $5 \mathrm{~cm}$ sediment of Poyang Lake. Vertical bars denote standard errors of means $(n=3)$.

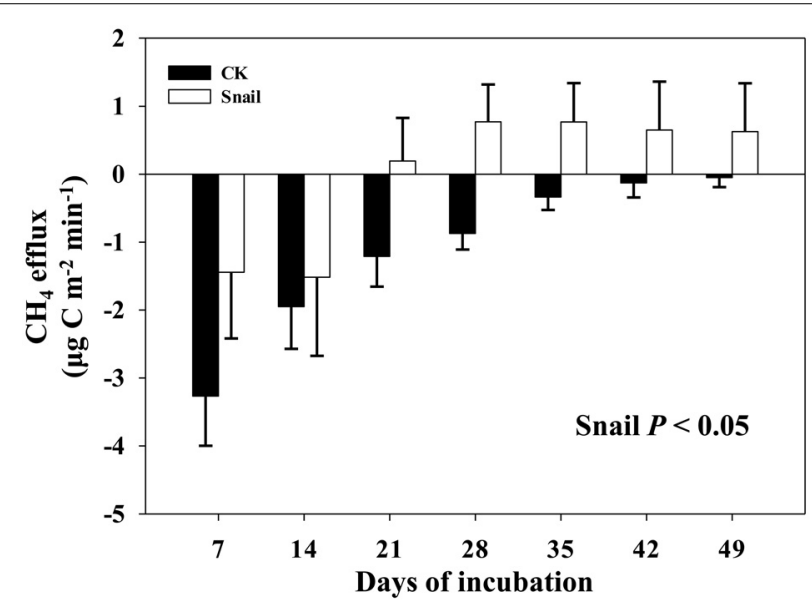

FIGURE 3 | $\mathrm{CH}_{4}$ effluxes monitored in the microcosm headspace every 7 days of freshwater snail treatment and defaunated control (CK). Vertical bars denote standard errors of means $(n=4)$.

Table 1 | Coefficients of Pearson's correlations between snail density, $\mathrm{CH}_{4}$ efflux, microbial activities and sediment properties across all 8 sampling sites.

\begin{tabular}{lccccccc}
\hline & $\mathbf{p H}$ & $\mathbf{N H}_{\mathbf{4}}^{+}$ & $\mathbf{N O}_{\mathbf{3}}^{-}$ & $\mathbf{D O N}$ & $\mathbf{D O C}$ & $\mathbf{T C}$ & $\mathbf{T N}$ \\
\hline Snail density & $0.71^{*}$ & $0.95^{* *}$ & -0.19 & $-0.74^{*}$ & 0.61 & 0.24 & 0.14 \\
$\mathrm{CH}_{4}$ efflux & 0.70 & $0.89^{*}$ & -0.24 & -0.64 & 0.53 & 0.21 & 0.11 \\
$\mathrm{PMP}$ & 0.50 & $0.71^{*}$ & -0.31 & -0.47 & 0.21 & 0.19 & 0.16 \\
$\mathrm{PMO}$ & $-0.77^{*}$ & $-0.83^{*}$ & -0.14 & $0.82^{*}$ & -0.38 & 0.06 & 0.03
\end{tabular}

$P M P$, potential $\mathrm{CH}_{4}$ production rate; $P M O$, potential $\mathrm{CH}_{4}$ oxidation rate; $\mathrm{DON}$, dissolved organic nitrogen; DOC, dissolved organic carbon; TC, total carbon; TN, total nitrogen. Asterisks mark different levels of significance: ${ }^{*} P<0.05,{ }^{*} P<$ $0.01,{ }^{* *} P<0.001$.

and thus the positive effects of freshwater snails on $\mathrm{CH}_{4}$ efflux (Figure 3) can be further confirmed.

Because $\mathrm{NH}_{4}^{+}$has a similar molecular size and structure to $\mathrm{CH}_{4}$, it can act as more aggressive substrate than $\mathrm{CH}_{4}$ and consequently competitively restrain $\mathrm{CH}_{4}$ oxidation (Schimel, 2000).
Therefore, $\mathrm{CH}_{4}$ oxidation might be inhibited by increased $\mathrm{NH}_{4}^{+}$ concentration in this study (Table 1) supporting previous results that $\mathrm{NH}_{4}^{+}$concentration can mediate $\mathrm{CH}_{4}$ oxidation (Smith et al., 2000). $\mathrm{NH}_{4}^{+}$concentration is mediated by the combined effects of bioturbation, microbial mineralization rate, and faunal excretion in the habitats with infauna (Papaspyrou et al., 2007). As bioturbation, the physical rearrangement of sediment particles by epifauna was shown to stimulate water solubility of nutrient exchange between sediment and overlying-water (Zheng et al., 2011). The bioturbation of epifauna can facilitate nutrient releases from sediment by molecular or eddy diffusion (Kristensen et al., 2012), possibly resulting in increases in $\mathrm{NH}_{4}^{+}$concentration with snail density increasing. Gilbertson et al. (2012) found that epifauna could increase $\mathrm{N}$ mineralization by shifting bacterial community structure due to grazing and/or mucus secretion. In the present study, DON was negatively correlated with snail density (Table 1$)$ and $\mathrm{NH}_{4}^{+}(r=-0.84 ; P=$ $0.009)$, respectively. These results suggest that freshwater snails may stimulate DON mineralization, thereby increase $\mathrm{NH}_{4}^{+}$concentration. Similarly, Jordan et al. (2009) found that microbial mineralization rate was positively correlated with the density of benthic fauna. In addition, macrofauna can excrete excess nitrogen (ammonia, urea and other nitrogen compounds) to avoid the toxicity of ammonia as it accumulates in body tissues (Wright, 1995).

Sediment $\mathrm{pH}$ as a secondary determinant is an important abiotic factor in regulating $\mathrm{CH}_{4}$ cycling (Moore and Roulet, 1995). In the present study, $\mathrm{CH}_{4}$ oxidation was significantly decreased with sediment $\mathrm{pH}$ increasing to neutral $\mathrm{pH}$ (Table 1). In addition, $\mathrm{CH}_{4}$ efflux was marginally positively correlated with sediment $\mathrm{pH}(P=0.054)$ (Table 1). This is consistent with previous studies which demonstrated $\mathrm{CH}_{4}$ efflux decreased with $\mathrm{pH}$ deceasing from neutral $\mathrm{pH}$ because $\mathrm{CH}_{4}$-oxidizing bacteria favor mild acidic environments (Amaral et al., 1998). These results suggests that sediment $\mathrm{pH}$ had a positive relationship with $\mathrm{NH}_{4}^{+}$concentration $(r=0.76, P<0.05)$, possibly because released $\mathrm{NH}_{4}^{+}$ from SOM was replaced by sediment dissociative $\mathrm{H}^{+}$based on the cation exchange. Therefore, increased $\mathrm{pH}$ due to enhanced $\mathrm{NH}_{4}^{+}$ release by snail activities may restrain $\mathrm{CH}_{4}$ oxidizability in this study. 


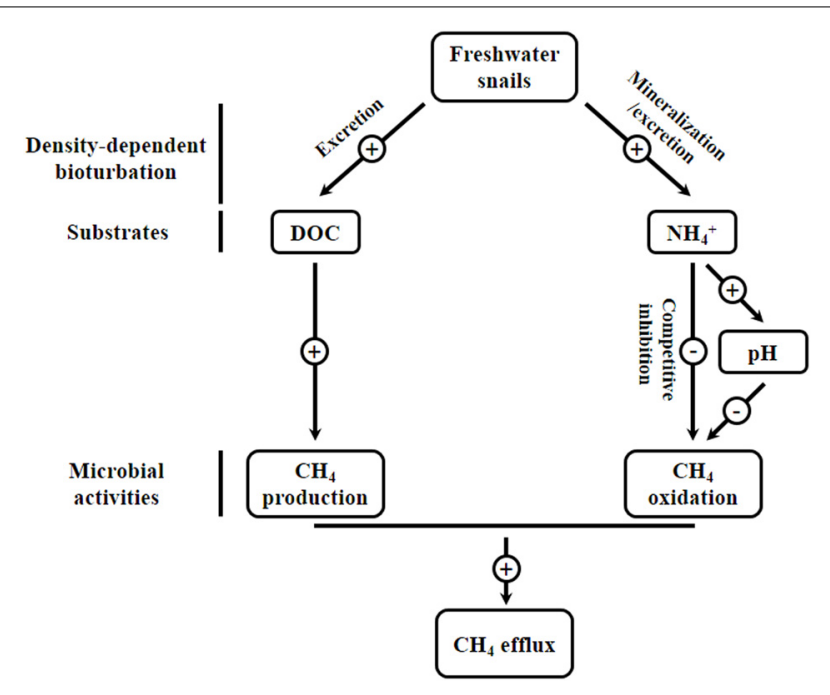

FIGURE 4 | Schematic presentation of the possible mechanisms of freshwater snail effects on the $\mathrm{CH}_{4}$ cycling in the investigated freshwater lake ecosystem.

Methanogens use a limited number of substrates for methanogenesis (Rother, 2010), thus substrate availability also is an important factor in regulating $\mathrm{CH}_{4}$ production (Le Mer and Roger, 2001). Methanogenesis is sensitive to the changes in DOC because DOC as available substrate can be rapidly utilized by methanogens or decomposed into the precursor substrates for $\mathrm{CH}_{4}$ production (Liu et al., 2011). Bergman et al. (2000) found that the absence of DOC strongly suppressed $\mathrm{CH}_{4}$ production rate in a peatland. Similarly, Liu et al. (2011) found that $\mathrm{CH}_{4}$ production rate was significantly correlated with the DOC in freshwater wetlands. A higher DOC in the habitat with a greater snail density can supply more substrates for methanogenesis (Table 1) and may promote (marginally significant, $P=0.10$ ) $\mathrm{CH}_{4}$ efflux (Table 1) in this study.

$\mathrm{O}_{2}$ availability largerly detemines $\mathrm{CH}_{4}$ cycling. In wetlands, $\mathrm{CH}_{4}$ oxidation increased with $\mathrm{O}_{2}$ concentration in the rhizospheres of emergent plants, because the plants enhance transportion of $\mathrm{O}_{2}$ from atmosphere to their rhizospheres (Laanbroek, 2010). Similarily, infauna chironomid larvae can also stimulate $\mathrm{CH}_{4}$ oxidation by increasing $\mathrm{O}_{2}$ diffusion into flooded rice soil (Kajan and Frenzel, 1999). But this may not occur in the habitats of epifauna. As the limited horizontal activities, epifauna may have little effect on transport of $\mathrm{O}_{2}$ into the sediments (Kristensen et al., 2012), suggesting that $\mathrm{CH}_{4}$ oxidation and methanogenesis may not be stimulated and inhibited in the habitats of epifauna. $\mathrm{O}_{2}$ availability was not measured in the sediments and water column due to the damage of $\mathrm{O}_{2}$ electrode in the field. Further works are required to inverstigate whether epifauna can affect biogenochemical cycling through regulating $\mathrm{O}_{2}$ availability.

As an intermittently inundated wetland, Liu et al. (2011) indicated that Poyang Lake might not be a strong source of $\mathrm{CH}_{4}$ in comparison to other permanently inundated wetlands such as Sanjiang Plain marsh in China. In the present study, mean $\mathrm{CH}_{4}$ efflux in snails' habitats $\left(15.33 \mathrm{mg} \mathrm{CH}_{4}-\mathrm{C} \mathrm{m}^{-2} \mathrm{~d}^{-1}\right)$ are comparable to $62 \%$ of those emitted from Spartina alterniflora dominated coastal marsh (24.72 $\mathrm{mg} \mathrm{CH}_{4}-\mathrm{C} \mathrm{m}^{-2} \mathrm{~d}^{-1}$ ) (Ding et al., 2010) and $46 \%$ of those emitted from Potamogetondominated alpine wetland $\left(33.1 \mathrm{mg} \mathrm{CH}_{4}-\mathrm{C} \mathrm{m}^{-2} \mathrm{~d}^{-1}\right.$ ) (Hirota et al., 2004), respectively. In addition, numerous process-based models, such as wetland methane emission model (Cao et al., 1996), and Wetland-DNDC (Zhang et al., 2002), which depend on measurements at specific sites or from specific sources to determine efflux by various important parameters such as climate and vegetation (Cao et al., 1996) may underestimate freshwater ecosystem $\mathrm{CH}_{4}$ efflux. For example, plant growth in terms of net ecosystem productivity plays a critical role in stimulating $\mathrm{CH}_{4}$ efflux in the Wetland-DNDC model (Zhang et al., 2002). However, the results in this study suggest that snails' habitats might be a strong source of $\mathrm{CH}_{4}$ in the non-plant-covered zones. Consequently, a better understanding of the impact of benthic fauna on $\mathrm{CH}_{4}$ cycling will contribute to improved accuracy of model-based predictions of $\mathrm{CH}_{4}$ effluxes from wetlands.

In summary, these results provide evidence that snails' habitats in a freshwater ecosystem are strong sources of $\mathrm{CH}_{4}$. Increased $\mathrm{CH}_{4}$ efflux may attribute to snail-induced stimulation in methanogenesis by supplying available substrates (DOC) and inhibition in $\mathrm{CH}_{4}$ oxidation by increasing $\mathrm{NH}_{4}^{+}$concentration and sediment $\mathrm{pH}$ (Figure 4). Given the important role of freshwater epifauna in mediating $\mathrm{CH}_{4}$ cycling, there is a clear need to enhance the understanding of the processes controlling $\mathrm{CH}_{4}$ dynamics, a major greenhouse gas dynamics.

\section{ACKNOWLEDGMENTS}

Thank Naishun $\mathrm{Bu}$ and Chenhao Zhou for assisting $\mathrm{CH}_{4}$ measurement and other laboratory works. This work was supported by National Basic Research Program of China (Grant No. 2010CB950602), China Postdoctoral Science Foundation (No. 201104552) and Shanghai Municipal Science and Technology Commission (No. 11440502300).

\section{SUPPLEMENTARY MATERIAL}

The Supplementary Material for this article can be found online at: http://www.frontiersin.org/journal/10.3389/fenvs.2014. 00012/abstract

\section{REFERENCES}

Amaral, J. A., Ren, T., and Knowles, R. (1998). Atmospheric methane consumption by forest soils and extracted bacteria at different $\mathrm{pH}$ values. Appl. Environ. Microbial. 64, 2397-2402.

Bergman, I., Klarqvist, M., and Nilsson, M. (2000). Seasonal variation in rates of methane production from peat of various botanical origins: effects of temperature and substrate quality. FEMS Microbiol. Ecol. 33, 181-189. doi: 10.1111/j.1574-6941.2000.tb00740.x

Bodelier, P. L. E., and Frenzel, P. (1999). Contribution of methanotrophic and nitrifying bacteria to $\mathrm{CH}_{4}$ and $\mathrm{NH}_{4}^{+}$oxidation in the rhizosphere of rice plants as determined by new methods of discrimination. Appl. Environ. Microbial. 65, 1826-1833.

Bodelier, P. L. E., Stomp, M., Santamaria, L., Klaassen, M., and Laanbroek, H. J. (2006). Animal-plant-microbe interactions: direct and indirect effects of swan foraging behaviour modulate methane cycling in temperate shallow wetlands. Oecologia 149, 233-244. doi: 10.1007/s00442-006-0445-9

Cao, M., Marshall, S., and Gregson, K. (1996). Global carbon exchange and methane emissions from natural wetlands: application of a process-based model. J. Geophys. Res. 101, 14399-14414. doi: 10.1029/96JD00219 
Ding, W., Zhang, Y., and Cai, Z. (2010). Impact of permanent inundation on methane emissions from a Spartina alterniflora coastal salt marsh. Atmos. Environ. 44, 3894-3900. doi: 10.1016/j.atmosenv.2010.07.025

Dingemans, B. J. J., Bakker, E. S., and Bodelier, P. L. E. (2011). Aquatic herbivores facilitate the emission of methane from wetlands. Ecology 92, 1166-1173. doi: 10.1890/i0012-9658-92-5-1166

Gilbertson, W. W., Solan, M., and Prosser, J. I. (2012). Differential effects of microorganism-invertebrate interactions on benthic nitrogen cycling. FEMS Microbiol. Ecol. 82, 11-22. doi: 10.1111/j.1574-6941.2012.01400.x

Hirota, M., Tang, Y., Hu, Q., Hirata, S., Kato, T., Mo, W., et al. (2004). Methane emissions from different vegetation zones in a Qinghai-Tibetan Plateau wetland. Soil Biol. Biochem. 36, 737-748. doi: 10.1016/j.soilbio.2003.12.009

IPCC. (2013). "Climate change 2013: the physical science basis," in Contribution of Working Group I to the Fifth Assessment Report of the Intergovernmental Panel on Climate Change, eds T.F. Stocker and D. Qin (Cambridge: Cambridge University Press), 1535.

Jordan, M. A., Welsh, D. T., Dunn, R. J. K., and Teasdale, P. R. (2009). Influence of Trypaea australiensis population density on benthic metabolism and nitrogen dynamics in sandy estuarine sediment: a mesocosm simulation. J. Sea Res. 61, 144-152. doi: 10.1016/j.seares.2008.11.003

Kajan, R., and Frenzel, P. (1999). The effect of chironomid larvae on production, oxidation and fluxes of methane in a flooded rice soil. FEMS Microbiol. Ecol. 28, 121-129. doi: 10.1111/j.1574-6941.1999.tb00567.x

Kristensen, E., Penha-Lopes, G., Delefosse, M., Valdemarsen, T., Quintana, C. O., and Banta, G. T. (2012). What is bioturbation? The need for a precise definition for fauna in aquatic sciences. Mar. Ecol. Prog. Ser. 446, 285-302. doi: 10.3354/meps09506

Laanbroek, H. J. (2010). Methane emission from natural wetlands: interplay between emergent macrophytes and soil microbial processes. A mini-review. Ann. Bot. 105, 141-153. doi: 10.1093/aob/mcp201

Laverock, B., Gilbert, J. A., Tait, K., Osborn, A. M., and Widdicombe, S. (2011). Bioturbation: impact on the marine nitrogen cycle. Biochem. Soc. Trans. 39, 315. doi: 10.1042/BST0390315

Le Mer, J., and Roger, P. (2001). Production, oxidation, emission and consumption of methane by soils: a review. Eur. J. Soil Biol. 37, 25-50. doi: 10.1016/S11645563(01)01067-6

Liu, D., Ding, W., Jia, Z., and Cai, Z. (2011). Relation between methanogenic archaea and methane production potential in selected natural wetland ecosystems across China. Biogeosciences 8, 329-338. doi: 10.5194/bg-8-329-2011

Mermillod-Blondin, F., and Rosenberg, R. (2006). Ecosystem engineering: the impact of bioturbation on biogeochemical processes in marine and freshwater benthic habitats. Aquat. Sci. 68, 434-442. doi: 10.1007/s00027-006-0858-x

Moore, T., and Roulet, N. (1995). "Methane emissions from Canadian peatlands," in Soils and Global Change, eds R. Lal and J.M. Kimble (Boca Raton, FL: CRC Press), 153-164.

Papaspyrou, S., Kristensen, E., and Christensen, B. (2007). Arenicola marina (Polychaeta) and organic matter mineralisation in sandy marine sediments: in situ and microcosm comparison. Estuar. Coast. Shelf Sci. 72, 213-222. doi: 10.1016/j.ecss. 2006.10 .020
Rother, M. (2010). "Methanogenesis," in Handbook of Hydrocarbon and Lipid Microbiology, eds K. Timmis and T. McGenity (Berlin; Heidelberg: Springer), 481-499. doi: 10.1007/978-3-540-77587-4_36

Schimel, J. (2000). Global change: rice, microbes and methane. Nature 403, 375-377. doi: 10.1038/35000325

Smith, K., Dobbie, K., Ball, B., Bakken, L., Sitaula, B., Hansen, S., et al. (2000). Oxidation of atmospheric methane in Northern European soils, comparison with other ecosystems, and uncertainties in the global terrestrial sink. Global Change Biol. 6, 791-803. doi: 10.1046/j.1365-2486.2000. 00356.x

Wang, H. Z., Xu, Q. Q., Cui, Y. D., and Liang, Y. L. (2007). Macrozoobenthic community of Poyang Lake, the largest freshwater lake of China, in the Yangtze floodplain. Limnology 8, 65-71. doi: 10.1007/s10201006-0190-0

Weyhenmeyer, G. A., Figueiredo-Barros, M. P., Caliman, A., Leal, J. J. F., Bozelli, R. L., Farjalla, V. F., et al. (2009). Benthic bioturbator enhances $\mathrm{CH}_{4}$ fluxes among aquatic compartments and atmosphere in experimental microcosms. Can. J. Fish Aquat. Sci. 66, 1649-1657. doi: 10.1139/F09-111

Whalen, S. (2005). Biogeochemistry of methane exchange between natural wetlands and the atmosphere. Environ. Eng. Sci. 22, 73-94. doi: 10.1089/ees.2005.22.73

Wright, P. A. (1995). Nitrogen excretion: three end products, many physiological roles. J. Exp. Biol. 198, 273-281.

Zhang, Y., Li, C., Trettin, C. C., Li, H., and Sun, G. (2002). An integrated model of soil, hydrology, and vegetation for carbon dynamics in wetland ecosystems. Global Biogeochem. Cy. 16, 9.1-9.17. doi: 10.1029/2001GB001838

Zheng, Z., Lv, J., Lu, K., Jin, C., Zhu, J., and Liu, X. (2011). The impact of snail (Bellamya aeruginosa) bioturbation on sediment characteristics and organic carbon fluxes in an eutrophic pond. Clean-Soil Air Water 39, 566-571. doi: $10.1002 /$ clen.201000212

Conflict of Interest Statement: The authors declare that the research was conducted in the absence of any commercial or financial relationships that could be construed as a potential conflict of interest.

Received: 19 February 2014; paper pending published: 10 March 2014; accepted: 28 April 2014; published online: 15 May 2014.

Citation: Xu X, Zhao W, Xiao M, Huang J, Fang C, Li B and Nie M (2014) Snails promote methane release from a freshwater lake ecosystem. Front. Environ. Sci. 2:12. doi: 10.3389/fenvs.2014.00012

This article was submitted to Interdisciplinary Climate Studies, a section of the journal Frontiers in Environmental Science.

Copyright (c) $2014 \mathrm{Xu}$, Zhao, Xiao, Huang, Fang, Li and Nie. This is an openaccess article distributed under the terms of the Creative Commons Attribution License (CC BY). The use, distribution or reproduction in other forums is permitted, provided the original author(s) or licensor are credited and that the original publication in this journal is cited, in accordance with accepted academic practice. No use, distribution or reproduction is permitted which does not comply with these terms. 